\title{
Different stress from parasites and mate choice in two female morphs of the blue-tailed damselfly
}

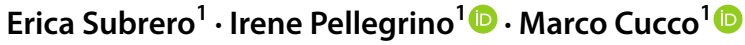

Received: 13 March 2021 / Accepted: 28 July 2021 / Published online: 11 August 2021

(c) The Author(s) 2021

\begin{abstract}
In Odonates, female colour polymorphism is common and implies the presence of two or more female types with different colours and behaviours. To explain this phenomenon, several hypotheses have been proposed that consider morph frequency, population density, the presence of parasites, and mating behaviour. We studied the blue-tailed damselfly Ischnura elegans, a species with a blue androchrome morph and two gynochrome morphs (the common green infuscans, and the rare orange rufescens-obsoleta). The size of adult males and females, the presence of parasites, and pairing behaviour between males and the three female morphs was assessed in field conditions throughout the reproductive season in NW Italy. Moreover, growth and emergence success of larvae produced by the different morphs was analyzed in standardized conditions. In the field, males showed a preference for the gynochrome infuscans females, despite a similar frequency of androchrome females. In test conditions, male preference for the infuscans females was also observed. Paired males and paired androchrome females were larger than unpaired individuals, while there were no differences in size between paired and unpaired infuscans females. Males and androchrome females were more parasitized than infuscans females. The survival and emergence success of larvae produced by androchrome females was higher than those of offspring produced by the infuscans females. Our results suggest that a higher survival of progeny at the larval stage could counterbalance the higher parasitism and the lower pairing success of andromorph adult females and highlight the importance of considering the whole life-cycle in polymorphism studies.
\end{abstract}

Keywords Female morphs $\cdot$ Parasites $\cdot$ Larval growth $\cdot$ Mate preference $\cdot$ Damselfly

\section{Introduction}

Polymorphism occurs when two or more morphs coexist in the same population (Burns 1956; Gray and McKinnon 2007). In dragonflies and damselflies, a particular kind of polymorphism, the female-limited colour polymorphism, is widespread (more than 100 species in the Holarctic region, Fincke et al. 2005). Usually, the coloration of the thorax

Marco Cucco

marco.cucco@uniupo.it

1 Università del Piemonte Orientale, Alessandria, Italy 
and abdomen of a female morph resembles the male (androchrome female), while one or more morphs show a different coloration (gynochrome females). The polymorphism shows a strong genetic determination with the colour being controlled by a single autosomal locus with female-limited expression in different species studied so far (Johnson 1964, 1966; Cordero 1990; Andrés and Cordero 1999; Abbott and Svensson 2005; Sanmartín-Villar and Cordero-Rivera 2016).

To explain the maintenance of polymorphism in Odonates, several hypotheses were proposed. According to the "reproductive isolation" hypothesis (Johnson 1975) gynochrome females are more cryptic, but suffer a high harassment by males of different species (interspecific), while androchrome females are not sexually harassed but suffer a greater pressure by predators. Similarly, the "male mimicry" hypothesis (Robertson 1985) proposes that androchrome females could benefit from less intense intraspecific male harassment (unnecessary matings can be very costly), but suffer a higher predation risk due to having more showy colours. The "density-dependent" hypothesis proposed by Hinnekint (Hinnekint 1987) implies that androchrome females could benefit by a less intense male harassment at high male densities, but face greater mating failure than gynochromes at low densities. The existence of temporal cyclic variation in population density would permit the different morphs to achieve an evolutionary equilibrium.

Other hypotheses stress the behavioural component of this phenomenon and are often limited to a single or few species. According to the "learned mate recognition" hypothesis (Miller and Fincke 1999) male choice is influenced by female morph frequency, and males choose the commonest morph. The "female aggression" hypothesis (Sirot et al. 2003) underlines that androchrome females can limit harassments, because they are more aggressive toward males than gynochromes, while the "female receiver" hypothesis (Sirot and Brockmann 2001) highlights that androchrome aggressive females disrupt and interfere more with other females during oviposition, and another hypothesis by Van Noordwijk (1978) suggested that males might disrupt more the oviposition behaviour of gynochromes compared to androchromes. According to the "signal detection" hypothesis (Sherratt and Forbes 2001), frequency-dependent and frequency-independent factors combine to generate a balanced polymorphism, in which andromorphs are not only more similar to males, but are also encountered more by males. The "male harassment" hypothesis (Gosden and Svensson 2007) proposes that female morphs differ in their propensity to accept male mating attempts and in their degree of resistance towards mating attempts. Maintenance of polymorphism within a population is an evolutionary enigma, because a slight consistent advantage of one morph would be sufficient for selection to drive the other morphs to extinction (Brockmann 2001; Galicia-Mendoza et al. 2017).

Recently, two hypotheses emphasize the role of internal (physiological maturation) or external (parasites) conditions to maintain female morphs. According to the "sexual status signalling" hypothesis (Huang and Reinhard 2012) sexually immature females change their colour from androchrome to gynomorphic to signal sexual maturity and regulate reproduction. The "parasitism" hypothesis (Sánchez-Guillén et al. 2013b) considers an important role of parasites on morph fitness: androchrome females are more successful in evading male harassment, but pay a higher fecundity cost by being more parasitized than gynochromes.

Despite the plethora of hypotheses proposed to explain female polymorphism, its adaptive significance remains controversial. The fitness consequences maintaining female polymorphisms in natural populations are difficult to be adequately demonstrated (Fincke 1994; Wellenreuther et al. 2014), and different hypotheses are not always mutually exclusive. 
Odonates, like other insect taxa, show two distinct life-history stages. During the course of ontogeny, they switch from being aquatic larvae to being terrestrial adults. Usually, research has examined the effect of behaviour and/or environmental conditions during the adult stage on mating success (Corbet 1980; Van Gossum et al. 2005), while less studies concerned the larval stage (Harvey and Corbet 1985). The trans generational effects of adult behaviour on the fitness of their progeny have been little studied (Thompson et al. 2011). Despite the wide occurrence of female polymorphism in Odonates, few studies have examined the growth and survival of the progeny generated by different female morphs (Abbott and Svensson 2005; Bots et al. 2010a; Bouton et al. 2011; Abbott 2013). Such studies are important, since fitness will ultimately depend upon selection that operates along successive generations (Stearns 1992).

In this study, we examined the Blue-tailed damselfly Ischnura elegans, a species where males are monomorphic while females occur in an androchrome and two gynochrome female morphs (forma infuscans and forma rufescens-obsoleta: (Parr 1999; SánchezGuillén et al. 2005). These morphs coexist in the same areas, and the frequency of each morph may vary among populations in the same season and among different seasons in the same population (Svensson and Abbott 2005; Hammers and Van Gossum 2008; Gosden and Svensson 2009). We collected biometrical data, sex ratio, morph frequency, mating success, and parasite burden for different morphs. We then tested the male preference for different morphs in controlled conditions through a binary test choice experiment. Finally, the fitness larval component for different female morphs was assessed by monitoring the hatching success, larval growth, and emergence success of the progeny produced by females.

\section{Methods}

\section{Study areas}

The studied populations were located at two artificial wetlands and one natural oxbow near the Po river (Alessandria, NW Italy). Lago Altafiore, Castellazzo Bormida AL $\left(44.85785^{\circ} \mathrm{N}\right.$, $8.59319^{\circ} \mathrm{E}$ ) is a 4.4 ha lake dedicated to sport fishing that was artificially created after gravel pit extraction activity. The basin has rather deep waters and steep banks, with fairly abundant aquatic vegetation in the first meter at the ground-water boundary and some Phragmites reed. Cava Allara, Sezzadio AL $\left(44.78991^{\circ} \mathrm{N}, 8.55177^{\circ}\right.$ E) is a 15.3 ha lake artificially created after gravel pit extraction activity, with slightly inclined shores, shallow water, and some floating and submerged vegetation. Phragmites and Typha are widespread. Lanca di San Bernardo, Valenza AL $\left(45.03701^{\circ} \mathrm{N}, 8.65516^{\circ} \mathrm{E}\right)$ has a surface of 2.8 ha and has lentic water with natural habitat coenosis characterized by abundant floating and submerged vegetation of different species. The vegetation is dominated by marsh plants, such as Carex spp., Phragmites spp., Juncus spp. and Typha spp., that are widespread along the shoreline.

\section{Field census}

Damselflies were captured with entomological nets and marked with a progressive number on the wing to avoid measuring the same individual twice. We never utilized observational data of individuals that were sight in the field but not captured. Sampling was carried 
out during the hours with maximum activity, i.e. between 11:00 and 15:00, throughout the reproductive season from May to September in 2013 and 2014. We always collected individuals found in the same environment, i.e. grassy vegetation placed in a strip about 3-10 m near the edge of the water body. Immediately after capture, a photo was taken with a digital camera with the animal positioned on a graph paper. The image was later analyzed with the ImageJ 1.48 software (Schneider et al. 2012) and total body length was measured to the nearest $0.1 \mathrm{~mm}$. In the field, we recorded sex, morphotype of females, and the presence/absence of parasites. Odonates are commonly parasitized by the endoparasite gregarine Protozoa (Córdoba-Aguilar and Munguía-Steyer 2013; Gołab et al. 2013; SánchezGuillén et al. 2013b) and ectoparasite Arrenurus mites (Zawal 2006; Hassall et al. 2010). In this study, we only considered the ectoparasites because we could easily assess their presence when measuring adults (Forbes and Robb 2008), without killing the damselflies for endoparasite examination (Kaunisto et al. 2015). We did not collect any teneral individuals (when damselflies first emerge teneral individuals are duller in colour and their wings are translucent). Moreover, we did not include in statistical analysis the immature individuals (violacea and rufescens forms: Sánchez-Guillén et al. 2005). Immature individuals showed a high parasitization rate (parasitized immatures: $36.1 \%, \mathrm{~N}=379$; adults: $7.8 \%, \mathrm{~N}=793$ ), and were rarely found mating (mating immatures: $5.0 \%, \mathrm{~N}=379$; adults: $37.0 \%, \mathrm{~N}=956$ ).

\section{Mate choice}

We studied mate choice both by assessing the number of individuals of different morphs that were found unpaired or found mating (wheel position) in the field, and conducting mate choice standardized tests (van Gossum et al. 1999, 2001; see Cordero-Rivera and Andrés 2001 cautionary note on choice experiments). To compare the body length of damselfly morphs, at each visit to a site we randomly captured a sample (mean 30 ind., range 7-124 ind.) of non-paired individuals and of individuals engaged in mating pairs.

Mate choice tests were performed in field in the same area of capture using an insectary formed by a squared iron framework $(60 \times 100 \times 100 \mathrm{~cm})$, laid down on the grass and covered by a mosquito net. One male and two females of different morphs (androchrome and infuscans) were placed at the same time inside the insectary and observed for $30 \mathrm{~min}$. During this time, any interaction (grasping, tandem, wheel mating) between the male and one of the two females was considered as an indication of choice. In this study, males never tried to approach two different females during the test session.

\section{Growth and survival of progeny}

We utilized a standard lab method to assess growth and survival of the progeny (Cordero 1990; Bots et al. 2010a; Bouton et al. 2011; Locklin 2012; Piersanti et al. 2015). Females actively engaged in mating activity (wheel position) were captured in the field and successively transported to the laboratory. Mating males were immediately released. We only captured androchrome and infuscans females, because rufescens-obsoleta females were very uncommon in our study area. In the laboratory, each female was photographed, then placed individually in a plastic cup containing a small piece of wet tissue paper and a small amount of water to stimulate the oviposition (Fincke 1984; Abbott and Svensson 2005; Subrero et al. 2019). Each plastic cup was closed with a mosquito net and females were left for about $20 \mathrm{~h}$ with an artificial photoperiod 16-8 L-D during which females usually laid their eggs on the tissue paper. After egg deposition (1937 eggs from 18 androchrome and 
3323 eggs from 39 infuscans females, all from unparasitized individuals), each tissue paper was placed in a separate tray containing natural water under the same lighting conditions, and females were released in their original capture area.

After about 12-15 days, the eggs began to hatch and the larvae were fed daily with Artemia salina nauplii. In line with other studies (De Block and Stoks 2008; Abbott 2013; Álvarez et al. 2013), Artemia shrimps were the only food item used throughout the rearing period. Once a week, larvae were placed in a petri dish with graph paper and measured to the nearest $0.25 \mathrm{~mm}$ under a stereo microscope to evaluate growth. To assess mortality rates, larvae were counted three times a week. In the last part of the rearing period, the trays containing the developing larvae were covered by a light perforated veil and a small stick was inserted to allow the ones that had to transform to rise out of the water. Once damselflies emerged, they were counted to establish emergence success.

\section{Statistics}

The difference in adult body length throughout the season was investigated with a general mixed model lme4 package (Bates et al. 2015) with length as the dependent variable and Julian date, study site, year, and morph as predictors. Site and year were added as random effects. The relationship between sex-ratio and Julian date and site were independent variables.

The effect of parasites on body length was analyzed by general mixed models only in males and in two female morphs, i.e. androchrome and infuscans, due to the low sample size of the rufescens-obsoleta morph.

Mortality was compared for androchrome and infuscans progeny using survival analyses (Kaplan-Meier estimates) with the survival packages (Fox and Carvalho 2012; Therneau 2020) implemented in the R Commander plugin (Fox 2005) for the R software (R Core Team 2016). In the models, female ID was entered as a random effect using the "frailty" function.

\section{Results}

\section{Abundance and size of morphs in the field}

The sex ratio observed in the field was always male biased. There were about twice as many males per female at the beginning of the reproductive seasons, from June to July, with a significant increase in the sex ratio toward the end of the season, from August to September (Fig. 1a; $\chi^{2}=41.58$; d.f. $=4 ; P<0.001$ ).

There was a significantly different frequency of the three female morphs $\left(\chi^{2}=203.2\right.$; d.f. $=2 ; P<0.001, \mathrm{~N}=410$ ). The androchrome and infuscans morphs were the most abundant, while the rufescens-obsoleta was rarely found (3.4\%).

Males were significantly smaller than females $\left(\mathrm{F}_{3,1000}=9.58, P<0.001, \mathrm{~N}=1004\right)$. There was a tendency for infuscans females to be larger than androchrome females $\left(\mathrm{F}_{2,256}=1.805, P<0.07\right)$. The few rufescens-obsoleta females showed a conspicuous size variability (Fig. 2).

The size of males and all female morphs decreased across the season (Fig. 3), with early-season individuals larger than end-season ones (Males: length $=32.61-0.0291 *$ day, 
Fig. 1 Seasonal trend along the reproductive season of (a) sex ratio, and (b) frequency of the three female morphs

Fig. 2 Sizes of males (M) and females of three different morphs (androchrome, infuscans and rufescens-obsoleta). Different letters indicate significant differences among types
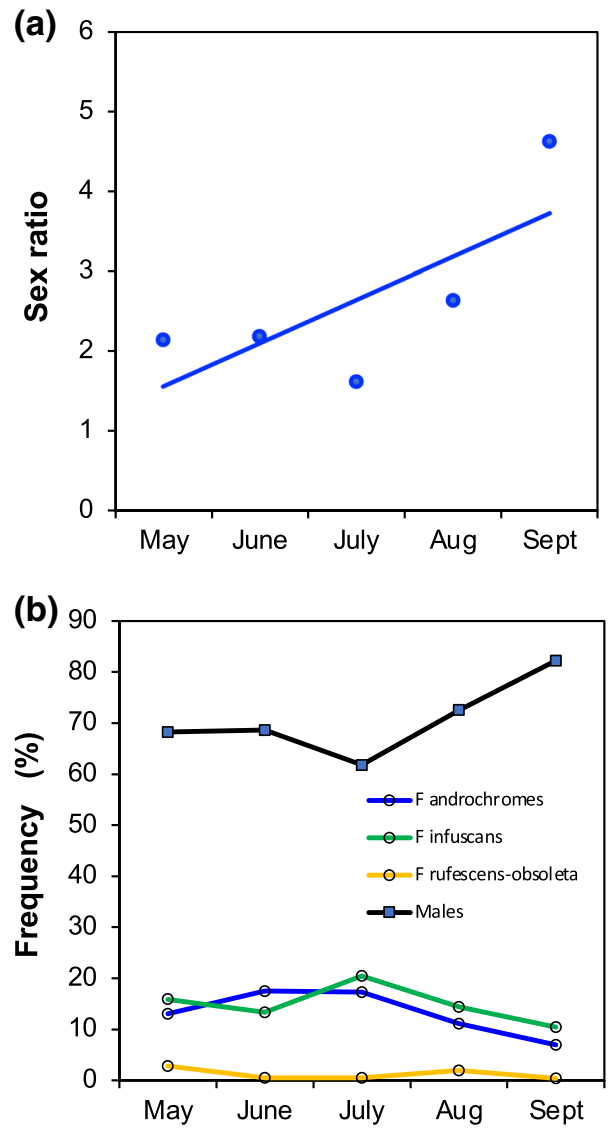

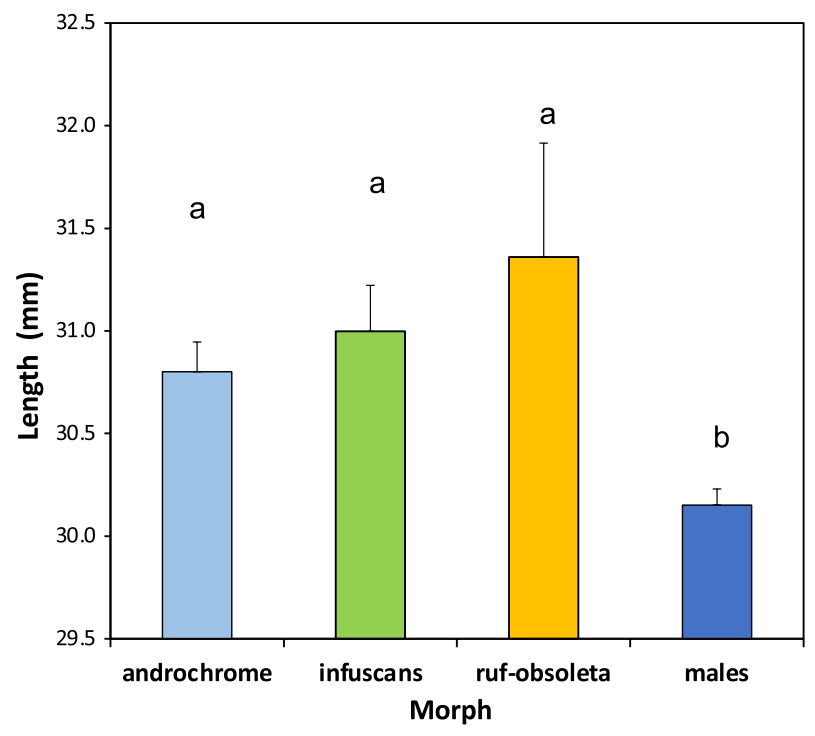



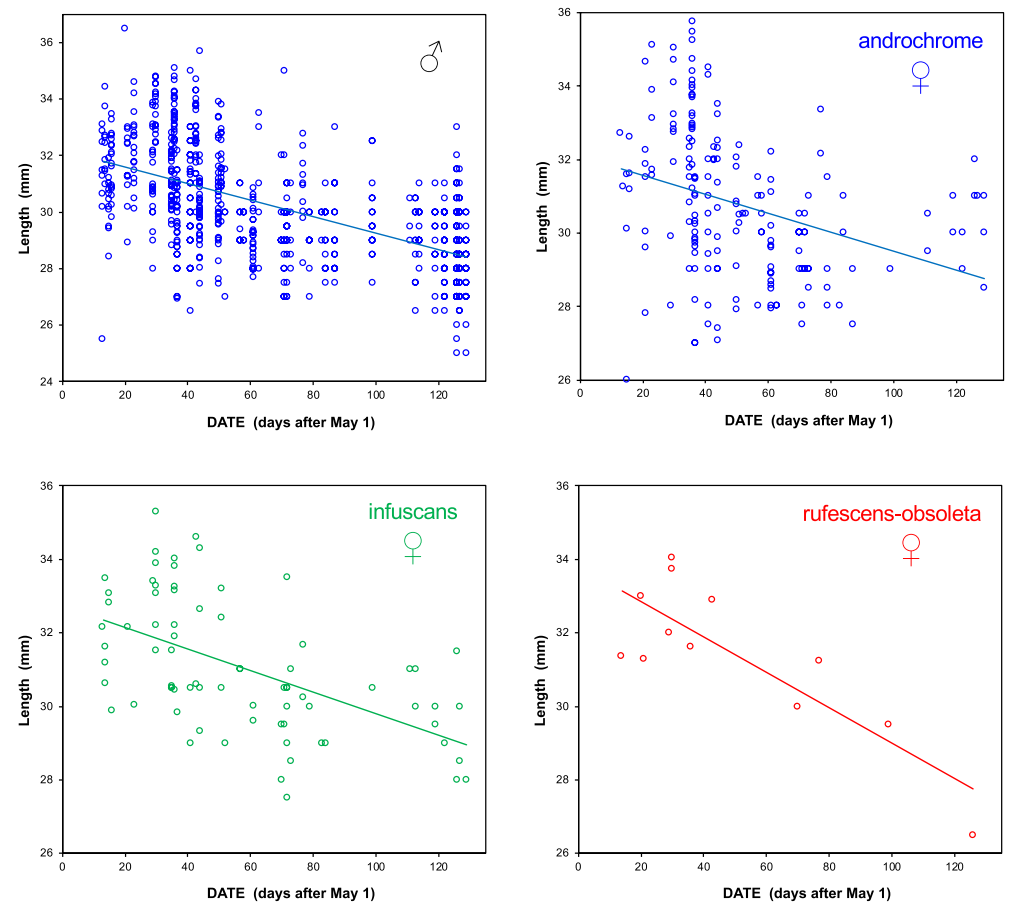

Fig. 3 Seasonal size trend for males and the three female morphs

$\mathrm{t}_{1,490}=336.9, P<0.001$; Androchomes: length $=32.14-0.0177 *$ day, $\mathrm{t}_{1,58}=4.92, P<0.03$; infuscans: length $=32.84-0.0302 *$ day, $\mathrm{t}_{1,67}=29.16, \quad P<0.001 ;$ rufescens-obsoleta: length $=33.99-0.0527 *$ day, $\left.\mathrm{t}_{1,5}=15.45, P<0.011\right)$.

\section{Mate choice}

Under field conditions, gynochrome infuscans were found mating significantly more than androchrome females (Logit unpaired $=0$, paired $=1$; effect of morph: androchrome $=-1.654, \mathrm{Z}=-7.308 ; P<0.001)$. The rufescens-obsoleta females were excluded from the analysis, because they were very uncommon in the study area. In relation to the increased proportion of males as the season progressed, the mating frequency of both androchrome and infuscans females increased along the reproductive period (Logit effect of Julian date: androchrome: effect $=0.0370, Z=6.611, P<0.001$. Infuscans: effect $=0.0150$, $\mathrm{Z}=2.742, P<0.001)$.

Paired males and paired androchrome females were larger than unpaired individuals, while infuscans females had similar sizes regardless of their pairing status (Fig. 4. Males: $\mathrm{t}_{2,491}=3.139, P<0.002$; androchrome: $\mathrm{t}_{2,57}=2.28, P=0.02 ;$ infuscans: $\mathrm{t}_{2,66}=1.071$, $P=0.29$ n.s.; rufescens-obsoleta: $\mathrm{t}_{2,4}=1.43, P=0.23$ n.s.).

In the binary choice test, infuscans were preferred over androchrome females (only 3 androchrome preferred out of 17 tests, Binomial test $P<0.0064)$. The time elapsed from 
Fig. 4 Sizes of paired $v s$ unpaired individuals

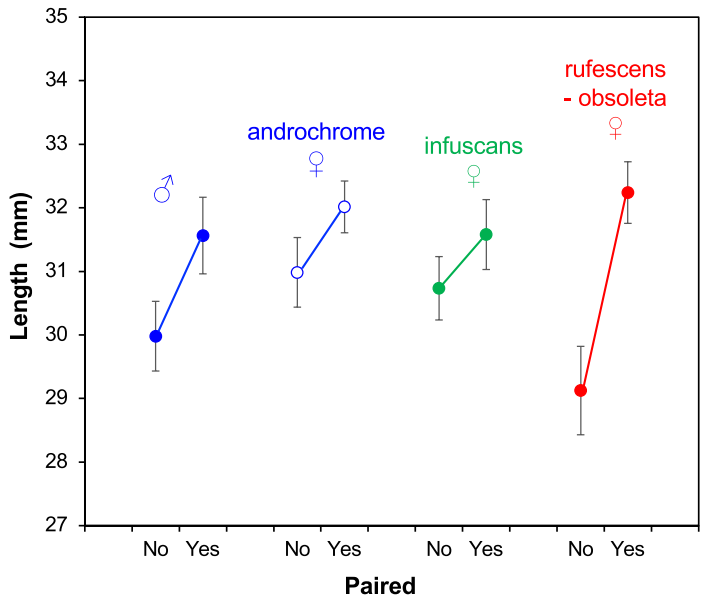

the beginning of the test to the first mating interaction was significantly lower for infuscans females $\left(10.0 \pm 5.77 \mathrm{~min}\right.$ vs $\left.25.0 \pm 5.0 \mathrm{~min} ; \mathrm{t}_{1,10}=3.09 ; P=0.011\right)$.

\section{Parasites}

Males were less parisitized than females (Yates corrected chi-square $=16.82$, d.f. $=1$; $P<0.001$ ), and this difference was largely due to androchrome females that were significantly more parasitized than both males and the other female morphs (Fig. 5; chisquare $=28.4$, d.f. $=3 ; P<0.001$ ).

Parasitized individuals of both sexes were significantly smaller than non-parasitized one (Table 1). The small sample size prevented any comparison for the rufescens-obsoleta morph.

Mating success of unparasitized individuals was higher than that of parasitized individuals (androchrome females: $57.0 \%$ vs $10.5 \%, \mathrm{~N}=98$, chi-square $=13.2, P=0.0003$;

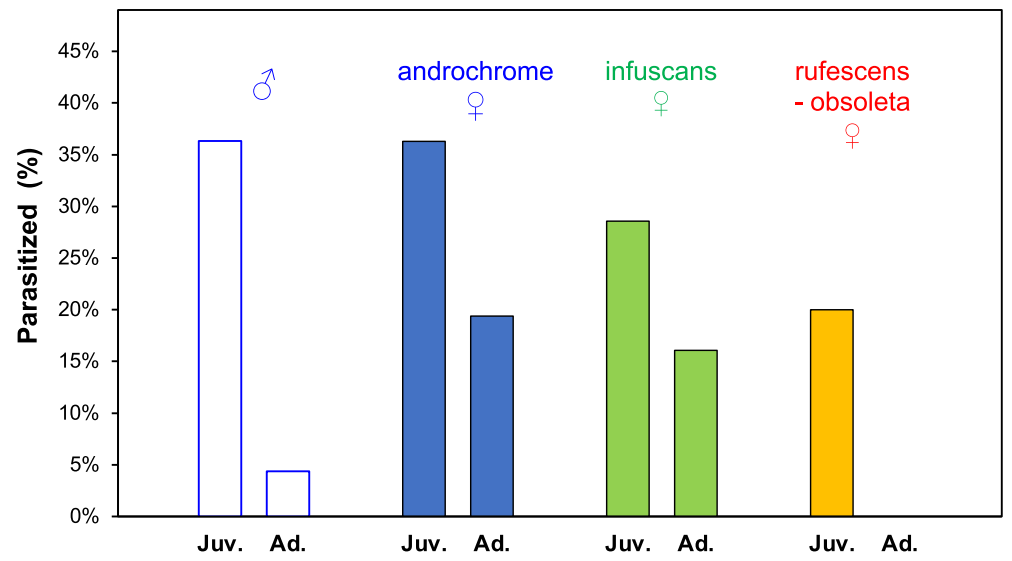

Fig. 5 Percentage of parasitized individuals for males and three female morphs 
Table 1 Sizes of parasitized versus unparasitized individuals in relation to Julian date and presence/absence of parasites

\begin{tabular}{llccrr}
\hline Morph & Constant & Julian date & Parasites & $\mathrm{t}$ & $\mathrm{p}$ \\
\hline Males & 32.878 & -0.0340 & -1.667 & 5.142 & $<0.001$ \\
Androchromes & 33.456 & -0.0280 & -2.458 & 5.696 & $<0.001$ \\
Gynochrome infuscans & 33.257 & -0.0333 & -0.889 & 2.032 & $<0.046$ \\
\hline
\end{tabular}

infuscans females: $69.1 \%$ vs $33.3 \%, \mathrm{~N}=112$, chi-square $=8.35, P=0.0039$; non-significant tendency for males: $21.4 \%$ vs $12.0 \%, \mathrm{~N}=572$, chi-square $=1.27, P=0.25$ ).

\section{Hatching rate, growth and survival of progeny}

The number of eggs laid by captured females of the two morphs did not significantly differ (androchrome: 107.6 $\pm 81.7 \mathrm{SD}, \mathrm{N}=18$; infuscans: 85.2 $\pm 90.7 \mathrm{SD}, \mathrm{N}=39$ females; Mann-Whitney test: $\mathrm{W}=442 ; P=0.12$ n.s.).

The hatching rate of eggs laid by androchromes were similar to that of eggs laid by infuscans females $(75.1 \%$ vs $71.6 \%$; $\mathrm{z}$ value $=0.609, P=0.543$ n.s. $)$.

Growth of larvae born from infuscans females was slightly higher than that of larvae born from androchrome females (Fig. 6a; mixed model with female identity as random effect: $\mathrm{N}$ observations $=6198$, groups $=48, \mathrm{t}=2.433, P=0.015)$. On the contrary, survival of progeny was significantly higher in larvae born from androchrome females (Fig. 6b; chisquare $=31.0$, d.f. $=1, P<0.001)$.

Success at emergence was significantly higher for progeny of androchrome females than for progeny of infuscans females (androchrome: $2.57 \%, \mathrm{~N}=75 / 2918$; infuscans: $1.77 \%$, $\mathrm{N}=96 / 5435$; chi-square $=5.86, P=0.015$ ).

\section{Discussion}

In this study we compared mate choice and survival of the progeny of different female morphs of the Blue-tailed damselfly. We found that androchrome females were slightly more frequent in nature and their progeny had better survival, while infuscans females were more chosen by males and less parasitized.

\section{Sex ratio and morphs frequency}

In our study area, sex ratio was always male-biased. Adult Odonates populations often have male-biased sex ratios at the breeding habitat (Corbet and Hoess 1998; Foster and Soluk 2006; Cordoba-Aguilar 2008). This bias could be attributed to a high female mortality, to females using alternative habitats (Stoks 2001; Johansson et al. 2005; Torres-Cambas and Fonseca-Rodríguez 2011), or to higher female mortality in the larval stage (Johansson et al. 2005). In some cases, it has been questioned as to whether male-biased sex ratios in Odonate populations are real or artificial, but current data suggest that the biased sex ratios are real (Stoks 2001). The continuous occurrence of a large number of males in our study species poses the basis for the presence of both intrasexual (male-male) and intersexual competitions. 
Fig. 6 Larval growth (a) and mortality of progeny (b) from androchrome and infuscans gynochrome females
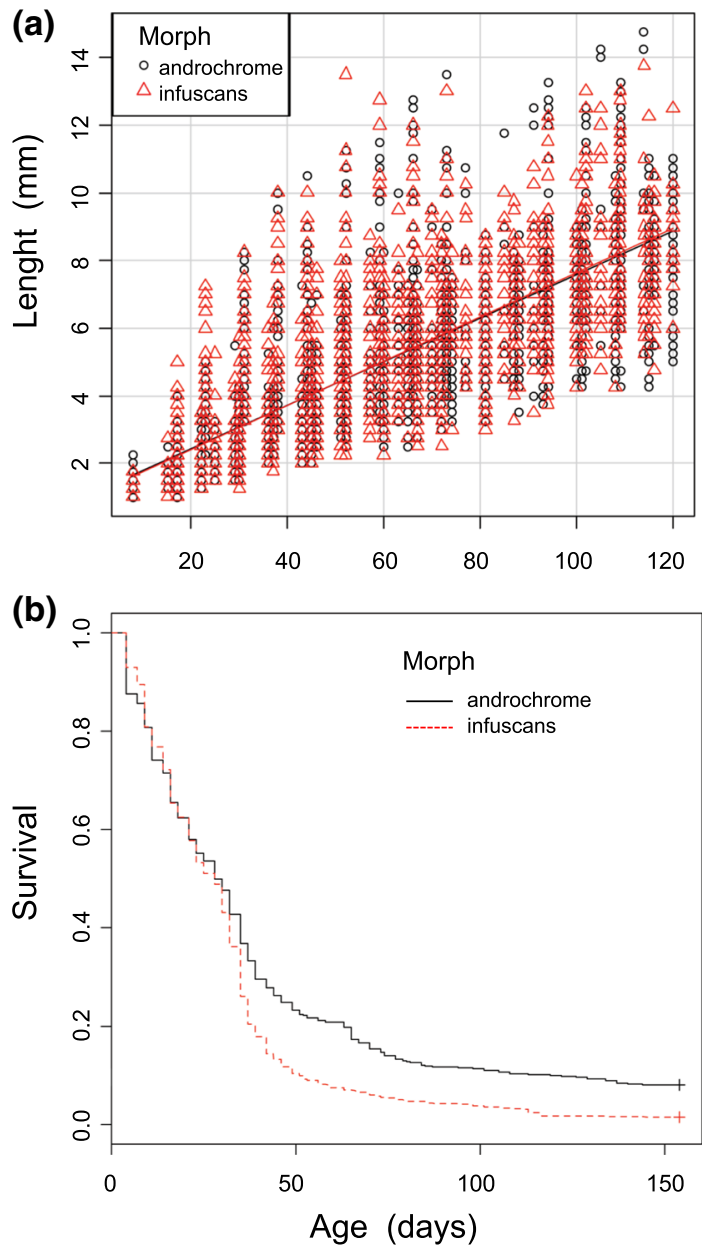

We found a different frequency of the three female morphs, with the andromorph slightly more abundant, the gynomorph infuscans rather frequent, and the gynomorph rufescens-obsoleta very rare. The morph frequency of female Odonates can vary across environmental gradients (Inomata et al. 2015; Bybee et al. 2016) or can vary cyclically when there is a fitness advantage of the rarer morph (Takahashi and Kawata 2013). In one study of Ischnura elegans, the morph frequencies had a pattern similar to those found in our study area, and were found to be stable over ten generations (Le Rouzic et al. 2015), while in other studies the proportion of the morphs varies between years, with more androchrome females in younger populations (Svensson and Abbott 2005), or with very large differences among nearby populations (Fincke et al. 2005; SánchezGuillén et al. 2005; Svensson et al. 2005). 


\section{Mate choice}

We found that androchrome females had a lower probability of being found in copula compared to the gynochrome morph: androchromes represented $55 \%$ of females but were involved in $43 \%$ of matings. Our result is similar to that reported for other populations of the same species (Cordero et al. 1998; Cordero-Rivera and Sánchez-Guillén 2007; Gosden and Svensson 2007, 2009; Hammers and Van Gossum 2008; Gosden et al. 2011). In the congeneric species Ischnura graellsii, mating success was similar for andro- and gynochrome morphs at high population densities, but the proportion of mated females was greater in gynochromes at low densities (Cordero 1992a). In Ischnura ramburi, andromorphs were less likely than gynomorphs to receive mating attempts by males, but did not mate less frequently than other females (Sirot et al. 2003).

The larger proportion of gynochrome females copulating in the field likely reflects the preference of males for that morph. The results of our experimental binary choice test confirm this hypothesis: the males preferred the gynochrome female when allowed to choose between the androchrome and infuscans. Our results on female pairing are in line with two other studies on the Blue-tailed damselfly, where a preference for gynochrome females was also found (Svensson et al. 2005; Sánchez-Guillén et al. 2017), but differs from other studies where males did not prefer gynochrome females but mated predominantly with the most common morph in the population (van Gossum et al. 1999). In general, male-female interactions may be very complex (Cordero et al. 1998; Cordero-Rivera and Sánchez-Guillén 2007; Sánchez-Guillén et al. 2013a), and may involve image search ability and learning (Punzalan et al. 2005; Nityananda 2016; but see Piersanti et al. 2021), multiple sensory cues (Van Gossum et al. 2008; Winfrey \& Fincke 2017; review in Rebora et al. 2018), and female behaviour in responding to mating attempts by males. Recent studies report that the preference for a specific morph may not be innate, but that male preference can be influenced by experience, i.e. naive males at their first encounter with a female did not show a clear preference for gynomorph individuals but the preference is shown later (SánchezGuillén et al. 2013a), and there is no long term memorization of preference because choice can vary the following day (Takahashi and Watanabe 2009).

A higher pairing success of gynochrome morphs was found in several damselfly species too. Indeed, male preference for gynochrome females seems to be a widespread pattern in Odonates (Cordero-Rivera and Andrés 2001).

\section{Size}

We found a strong sexual size dimorphism, with females larger than males. Sexual size dimorphism has been observed in several insect taxa. Fecundity selection acting on female body size usually produces female-biased dimorphism through increasing fecundity in larger females, but variations with respect to this pattern have been frequently found. For example, male-male competition can end with male-biased size dimorphism in species in which males compete for females on the ground, or female biased size dimorphism in species in which males compete in the air and manoeuvrability is favoured by small size (Serrano-Meneses et al. 2008). In Odonates, a female-biased sexual size dimorphism in non-territorial species and monomorphism for territorial species has been shown (WongMuñoz et al. 2011). Dimorphism can progress even from the early stages of life in eggs (Takahashi and Watanabe 2010a; Iserbyt et al. 2013). 
In our study, we found that gynochrome females were larger that androchrome females. Hence, androchrome females were somehow similar to the males even for size besides colour. A similar pattern was found in the same species in Sweden (Abbott and Gosden 2009), but this is not a general pattern of our study species (Cordero et al. 1998), nor within this damselfly genus, because in Ischnura graellsii either no difference or the reverse pattern was found (Cordero 1992a), nor is it a general pattern in other damselflies (Lajeunesse and Forbes 2003).

Our results indicated that both female and male Blue-tailed damselflies reached a smaller body size as the season progressed. The decrease in size within season is a common pattern in Odonates with the opposite having been found in a few species only (WongMuñoz et al. 2011).

Interestingly, paired males were larger than unpaired males. The morphometric difference between mated and unmated males suggests the presence of sexual selection acting on this trait. Our result contrasts with the small-male mating advantage hypothesis (Stoks 2000; De Block and Stoks 2007) which predicts that small males are advantaged by better manoeuvrability in flight. In Sweden's Blue-tailed damselflies, it has been reported that sexual selection on the male body size is mediated by densities of the two common female morphs, androchromes and gynochromes. High densities of androchrome females selected for small male body sizes, whereas high densities of gynochrome females selected for larger males (Gosden and Svensson 2008). Adult size is a highly hereditable trait in the Blue-tailed damselfly morphs (Abbott and Svensson 2010), as well as in other species (Cordero 1992b; Andrés and Cordero 1999; Abbott and Svensson 2005; Sánchez-Guillén et al. 2005). If larger males enjoy a higher pairing success, then a selective trend toward larger sizes should be at work. However, this predicted trend may hold only in gynochrome-rich populations. Moreover, it is difficult to predict pressures acting on adult size by considering just a single behavioural trait. Indeed, in the Common blue damselfly Enallagma cyathigerum, studies have failed to observe morph differences in size despite highly different levels of a behavioural trait in the form of male harassment (Bots et al. 2009).

\section{Parasites}

In our study, we found a noticeable difference between sexes and morphs in water mite parasitization rate. Males were less intensely parasitized than androchrome females which, in turn, were more parasitized than gynochrome females. Our result contrasts with the trend outlined in a recent review on parasite infestation, according to which the two sexes are generally equally parasitized in both dragonflies and damselflies (Ilvonen et al. 2016). However, a study on six species of damselflies showed that androchrome females suffer from a higher degree of parasitism than gynochrome females and males (Sánchez-Guillén et al. 2013b). Furthermore, a study on the Blue-tailed damselfly found that males were less parasitized than both gynochrome and androchrome females (Willink and Svensson 2017). From these contrasting findings, it appears that a general pattern of parasitic infestation in relation to sex and morph is difficult to extract from Odonate research. Probably, parasitization condition is mainly shaped by large between-species and between-populations differences. Parasite resistance too can differ between sexes and morphs. Recently, a comparison between male and female immunity identified genes with sex-biased expression, and gynochromes differed more from males than the androchrome females (Chauhan et al. 2016).

In our study, parasitized damselflies were smaller than non-parasitized. Our result is similar to findings on males of the Variable damselfly Coenagrion pulchellum 
(Hughes et al. 2016). Reduced size could be related to the negative effects of parasites, because water mites extract body fluids from their hosts. However, mites are acquired when tenerals leave the water during emergence (Forbes and Robb 2008; Stoks and CordobaAguilar 2012). Therefore, a negative effect of parasites on size seems to be unlikely in damselflies, which had already developed to their full body size after emergence (Hughes et al. 2016). Other possible explanations include the behavioural and the immune reactions of damselflies to parasites. Water mites attach themselves on to the ventral side of the host, and larval damselflies have been found to get rid of attached mites by grooming. It is possible that larger individuals can free themselves of the mites more effectively (Forbes and Baker 1990). Besides, body size could also be related to immunity. If larger individuals are able to allocate more resources towards their immune reaction, then their response (mite encapsulation) may be more efficient and the observed parasitization rate lower (Hughes et al. 2016). Lastly, the difference in size could be related to the age of damselflies. Arrenurus mites are found mainly in young individuals, and usually drop-off from the damselflies when they start to reproduce (Rolff 1999). Larger individuals may be able to survive longer and will also have less parasites, because they detach when the damselflies begin to reproduce. In this study, we excluded immature individuals (violacea and rufescens forms: Sánchez-Guillén et al. 2005), but in adults we did not control whether the unparasitized and larger individuals were older than parasitized ones. This hypothesis needs detailed studies in the future.

In Odonates, negative effects of parasites have also shown to be related to reduced egg production (Forbes and Baker 1991; Rolff 1999; Canales-Lazcano et al. 2005; but see Kaunisto et al. 2017), reduced mating success (this study; Forbes and Baker 1991; Andrés and Cordero 1998; Rolff 1999; Canales-Lazcano et al. 2005), or to increased mortality. In the Azure damselfly Coenagrion puella, mite load influenced the probability of daily resighting (Sherratt et al. 2010), or increased the likelihood of dispersal (Conrad et al. 2002).

\section{Larval growth}

In order to compare the two female morphs fitness, aside from pairing success and parasitisation rate, it is important to consider other fitness-related parameters, e.g. clutch size, egg hatching rate, and growth of the progeny.

In previous studies, female morphs of some species have been shown to differ in clutch size (Bots et al. 2009, 2010b; Bouton et al. 2011; Sánchez-Guillén et al. 2017; Khan 2020) and egg size (Takahashi and Watanabe 2010b; Takahashi and Kawata 2013), but in other species there was no difference (Iserbyt et al. 2013). In our study, we found a similar growth of larvae born from andromorph and gynomorph B-females. This result on growth rate is in line with the findings of (Abbott and Svensson 2008), who found that offspring from androchrome and infuscans have similar growth rates, but a different growth rate was found for offspring of the rare rufescens-obsoleta morph. However, we found that survival of the progeny during the growing period and the emergence rate differed between the two morphs, with a higher mortality of gynomorph progeny.

In conclusion, our results suggest that a higher survival of progeny of andromorph females at the larval stage could counterbalance the higher parasitization and the lower pairing success of andromorph adult females. Indeed, female fitness is related to adult mating behaviour and to ectoparasite burden (Thompson et al. 2011), but our results highlight the importance of considering the whole life-cycle in polymorphism studies (CordobaAguilar 2008). 
Acknowledgements We thank Giada Antonioli, Anna Vassallo and Alessia Fabbian for help in the field, and Emiliano Tambornini for help in the laboratory. Manuela Rebora introduced us to damselfly lab rearing techniques, and Giorgio Malacarne helped to set up the behavioural parts of the study. The research was supported by the University of Piemonte Orientale "Ricerca locale" Grant.

Funding Open access funding provided by Università degli Studi del Piemonte Orientale Amedeo Avogrado within the CRUI-CARE Agreement.

Open Access This article is licensed under a Creative Commons Attribution 4.0 International License, which permits use, sharing, adaptation, distribution and reproduction in any medium or format, as long as you give appropriate credit to the original author(s) and the source, provide a link to the Creative Commons licence, and indicate if changes were made. The images or other third party material in this article are included in the article's Creative Commons licence, unless indicated otherwise in a credit line to the material. If material is not included in the article's Creative Commons licence and your intended use is not permitted by statutory regulation or exceeds the permitted use, you will need to obtain permission directly from the copyright holder. To view a copy of this licence, visit http://creativecommons.org/licenses/by/4.0/.

\section{References}

Abbott JK (2013) Morph-specific and sex-specific temperature effects on morphology in the colour polymorphic damselfly Ischnura elegans. Anim Biol 63:149-167. https://doi.org/10.1163/1570756300002402

Abbott JK, Gosden TP (2009) Correlated morphological and colour differences among females of the damselfly Ischnura elegans. Ecol Entomol 34:378-386. https://doi.org/10.1111/j.1365-2311.2009. 01087.x

Abbott JK, Svensson EI (2005) Phenotypic and genetic variation in emergence and development time of a trimorphic damselfly. J Evol Biol 18:1464-1470. https://doi.org/10.1111/j.1420-9101.2005.01019.x

Abbott JK, Svensson EI (2008) Ontogeny of sexual dimorphism and phenotypic integration in heritable morphs. Evol Ecol 22:103-121. https://doi.org/10.1007/s10682-007-9161-0

Abbott JK, Svensson EI (2010) Morph-specific variation in intersexual genetic correlations in an intra-specific mimicry system. Evol Ecol Res 12:105-118

Álvarez HA, Serrano-Meneses MA, Reyes-Márquez I et al (2013) Allometry of a sexual trait in relation to diet experience and alternative mating tactics in two rubyspot damselflies (Calopterygidae: Hetaerina). Biol J Linn Soc 108:521-533. https://doi.org/10.1111/j.1095-8312.2012.02031.x

Andrés JA, Cordero A (1998) Effects of water mites on the damselfly Ceriagrion tenellum. Ecol Entomol 23:103-109. https://doi.org/10.1046/j.1365-2311.1998.00125.x

Andrés JA, Cordero A (1999) The inheritance of female colour morphs in the damselfly Ceriagrion tenellum (Odonata, Coenagrionidae). Heredity 82:328-335. https://doi.org/10.1038/sj.hdy.6884930

Bates D, Mächler M, Bolker B, Walker S (2015). Fitting linear mixed-effects models using lme4. J Stat Softw 67:1-48. https://doi.org/10.18637/jss.v067.i01

Bots J, Van Dongen S, Adriaens T et al (2009) Female morphs of a colour polymorphic damselfly differ in developmental instability and fecundity. Anim Biol 59:41-54. https://doi.org/10.1163/157075609X 417080

Bots J, De Bruyn L, Snijkers T et al (2010a) Exposure to perfluorooctane sulfonic acid (PFOS) adversely affects the life-cycle of the damselfly Enallagma cyathigerum. Environ Pollut 158:901-905. https:// doi.org/10.1016/j.envpol.2009.09.016

Bots J, van Dongen S, de Bruyn L et al (2010b) Clutch size and reproductive success in a female polymorphic insect. Evol Ecol 24:1239-1253. https://doi.org/10.1007/s10682-010-9362-9

Bouton N, Iserbyt A, Van Gossum H (2011) Thermal plasticity in life-history traits in the polymorphic blue-tailed damselfly, Ischnura elegans: no differences between female morphs. J Insect Sci 11:1-11. https://doi.org/10.1673/031.011.11201

Brockmann HJ (2001) The evolution of alternative strategies and tactics. Adv Study Behav 30:1-51. https:// doi.org/10.1016/S0065-3454(01)80004-8

Burns JM (1956) Problems in zoological polymorphism. Sci Mon 82:75-84

Bybee S, Córdoba-Aguilar A, Duryea MC et al (2016) Odonata (dragonflies and damselflies) as a bridge between ecology and evolutionary genomics. Front Zool 13:46-46. https://doi.org/10.1186/ s12983-016-0176-7 
Canales-Lazcano J, Contreras-Garduño J, Córdoba-Aguilar A (2005) Fitness-related attributes and gregarine burden in a non-territorial damselfly Enallagma praevarum hagen (Zygoptera: Coenagrionidae). Odonatologica 34:123-130

Chauhan P, Wellenreuther M, Hansson B (2016) Transcriptome profiling in the damselfly Ischnura elegans identifies genes with sex-biased expression. BMC Genomics 17:985. https://doi.org/10.1186/ s12864-016-3334-6

Conrad KF, Willson KH, Whitfield K et al (2002) Characteristics of dispersing Ischnura elegans and Coenagrion puella (Odonata): age, sex, size, morph and ectoparasitism. Ecography 25:439-445. https:// doi.org/10.1034/j.1600-0587.2002.250406.x

Corbet PS (1980) Biology of Odonata. Annu Rev Entomol 25:189-217. https://doi.org/10.1146/annurev.en. 25.010180.001201

Corbet PS, Hoess R (1998) Sex ratio of Odonata at emergence. Int J Odonatol 1:99-118. https://doi.org/10. 1080/13887890.1998.9748099

Cordero A (1990) The inheritance of female polymorphism in the damselfly Ischnura graellsii (Rambur) (Odonata: Coenagrionidae). Heredity 64:341-346. https://doi.org/10.1038/hdy.1990.42

Cordero A (1992a) Density-dependent mating success and colour polymorphism in females of the damselfly Ischnura graellsii (odonata: coenagrionidae). J Anim Ecol 61:769-780. https://doi.org/10.2307/5630

Cordero A (1992b) Morphological variability, female polymorphism and heritability of body length in Ischnura graellsii (Rambur) (zygoptera: coenagrionidae). Odonatologica 21:409-419

Cordero A, Santolamazza Carbone S, Utzeri C (1998) Mating opportunities and mating costs are reduced in androchrome female damselflies, Ischnura elegans (Odonata). Anim Behav 55:185-197. https://doi. org/10.1006/anbe.1997.0603

Cordero-Rivera A, Andrés JA (2001) Estimating female morph frequencies and male mate preferences of polychromatic damselflies: a cautionary note. Anim Behav 61:F1-F6. https://doi.org/10.1006/anbe. 2000.1572

Cordero-Rivera A, Sánchez-Guillén RA (2007) Male-like females of a damselfly are not preferred by males even if they are the majority morph. Anim Behav 74:247-252. https://doi.org/10.1016/j.anbehav. 2006.06.023

Cordoba-Aguilar A (2008) Dragonflies and damselflies. Oxford University Press, Oxford, Model organisms for ecological and evolutionary research

Córdoba-Aguilar A, Munguía-Steyer R (2013) The sicker sex: understanding male biases in parasitic infection, resource allocation and fitness. PLoS ONE. https://doi.org/10.1371/journal.pone.0076246

De Block M, Stoks R (2007) Flight-related body morphology shapes mating success in a damselfly. Anim Behav 74:1093-1098. https://doi.org/10.1016/j.anbehav.2007.01.023

De Block M, Stoks R (2008) Short-term larval food stress and associated compensatory growth reduce adult immune function in a damselfly. Ecol Entomol 33:796-801. https://doi.org/10.1111/j.1365-2311. 2008.01024.x

Fincke OM (1984) Sperm competition in the damselfly Enallagma hageni Walsh (Odonata: Coenagrionidae): benefits of multiple mating to males and females. Behav Ecol Sociobiol 14:235-240. https://doi. org/10.1007/BF00299623

Fincke OM (1994) Female colour polymorphism in damselflies: failure to reject the null hypothesis. Anim Behav 47:1249-1266

Fincke OM, Jödicke R, Paulson DR, Schultz TD (2005) The evolution and frequency of female color morphs in Holarctic Odonata: why are male-like females typically the minority? Int J Odonatol 8:183-212. https://doi.org/10.1080/13887890.2005.9748252

Forbes MRL, Baker RL (1990) Susceptibility to parasitism: experiments with the damselfly Enallagma ebrium (Odonata: Coenagrionidae) and larval water mites, Arrenurus spp. (Acari: Arrenuridae). Oikos 58:61-66. https://doi.org/10.2307/3565361

Forbes MRL, Baker RL (1991) Condition and fecundity of the damselfly, Enallagma ebrium (Hagen): the importance of ectoparasites. Oecologia 86:335-341. https://doi.org/10.1007/BF00317598

Forbes MR, Robb T (2008) Testing hypotheses about parasite-mediated selection using Odonate hosts. In: Córdoba-Aguilar A (ed) Dragonflies: model organisms for ecological and evolutionary research. Oxford University Press Inc., New York, New York, USA, pp 175-188

Foster SE, Soluk DA (2006) Protecting more than the wetland: the importance of biased sex ratios and habitat segregation for conservation of the Hine's emerald dragonfly, Somatochlora hineana Williamson. Biol Conserv 127:158-166. https://doi.org/10.1016/j.biocon.2005.08.006

Fox J (2005) The R commander: a basic-statistics graphical user interface to R. J Stat Softw 14:1-42

Fox J, Carvalho MS (2012) The RcmdrPlugin.survival package: extending the R commander interface to survival analysis. J Stat Softw 49:1-32 
Galicia-Mendoza I, Sanmartín-Villar I, Espinosa-Soto C, Cordero-Rivera A (2017) Male biased sex ratio reduces the fecundity of one of three female morphs in a polymorphic damselfly. Behav Ecol 28:1183-1194. https://doi.org/10.1093/beheco/arx086

Gołab MJ, Śniegula S, Drobniak SM et al (2013) Where do floaters settle? an experimental approach in odonates. Anim Behav 86:1069-1075. https://doi.org/10.1016/j.anbehav.2013.09.013

Gosden TP, Svensson EI (2007) Female sexual polymorphism and fecundity consequences of male mating harassment in the wild. PLoS ONE 2:e580. https://doi.org/10.1371/journal.pone.0000580

Gosden TP, Svensson EI (2008) Spatial and temporal dynamics in a sexual selection mosaic. Evolution 62:845-856. https://doi.org/10.1111/j.1558-5646.2008.00323.x

Gosden TP, Svensson EI (2009) Density-dependent male mating harassment, female resistance, and male mimicry. Am Nat 173:709-721. https://doi.org/10.1086/598491

Gosden TP, Stoks R, Svensson EI (2011) Range limits, large-scale biogeographic variation, and localized evolutionary dynamics in a polymorphic damselfly. Biol J Linn Soc 102:775-785. https://doi.org/10. 1111/j.1095-8312.2011.01619.x

Gray SM, McKinnon JS (2007) Linking color polymorphism maintenance and speciation. Trends Ecol Evol 22:71-79. https://doi.org/10.1016/j.tree.2006.10.005

Hammers M, Van Gossum H (2008) Variation in female morph frequencies and mating frequencies: random, frequency-dependent harassment or male mimicry? Anim Behav 76:1403-1410. https://doi.org/ 10.1016/j.anbehav.2008.06.021

Harvey IF, Corbet PS (1985) Territorial behaviour of larvae enhances mating success of male dragonflies. Anim Behav 33:561-565. https://doi.org/10.1016/S0003-3472(85)80079-8

Hassall C, Lowe CD, Harvey IF et al (2010) Phenology determines seasonal variation in ectoparasite loads in a natural insect population. Ecol Entomol 35:514-522. https://doi.org/10.1111/j.1365-2311.2010. 01210.x

Hinnekint BON (1987) Population dynamics of Ischnura e. elegans (vander linden) (insecta: odonata) with special reference to morphological colour changes, female polymorphism, multiannual cucles and their influence on behaviour. Hydrobiologia 146:3-31

Huang SC, Reinhard J (2012) Color change from male-mimic to gynomorphic: a new aspect of signaling sexual status in damselflies (odonata, zygoptera). Behav Ecol 23:1269-1275. https://doi.org/10.1093/ beheco/ars 112

Hughes M, Kaunisto KM, Suhonen J (2016) Large males have fewer water mites (Arrenurus sp.) on the variable bluet (coenagrion pulchellum) damselfly. Can J Zool 94:339-343. https://doi.org/10.1139/ cjz-2015-0208

Ilvonen JJ, Kaunisto KM, Suhonen J (2016) Are sexes equally parasitized in damselflies and dragonflies? Oikos 125:315-325. https://doi.org/10.1111/oik.02437

Inomata N, Hironaka K, Sawada K et al (2015) Discrepancy in the degree of population differentiation between color-morph frequencies and neutral genetic loci in the damselfly Ischnura senegalensis in Okinawa Island, Japan. Genetica 143:271-277. https://doi.org/10.1007/s10709-015-9821-x

Iserbyt A, Bots J, Van Gossum H, Sherratt TN (2013) Negative frequency-dependent selection or alternative reproductive tactics: maintenance of female polymorphism in natural populations. BMC Evol Biol 13:139-139. https://doi.org/10.1186/1471-2148-13-139

Johansson F, Crowley PH, Brodin T (2005) Sexual size dimorphism and sex ratios in dragonflies (Odonata). Biol J Linn Soc 86:507-513. https://doi.org/10.1111/j.1095-8312.2005.00549.x

Johnson C (1964) The inheritance of female dimorphismin the damselfy, Ischnura damula. Genetics 49:513-519. https://doi.org/10.1093/genetics/49.3.513

Johnson C (1966) Genetics of female dimorphism in Ischnura demorsa. Heredity 21:453-459. https://doi. org/10.1038/hdy.1966.44

Johnson C (1975) Polymorphism and natural selection in Ischnuran damselflies. Evol Theory 1:81-90

Kaunisto KM, Kaunisto P, Vahtera V, Suhonen J (2015) Populations of the damselfly Coenagrion hastulatum at the edge of the species range have fewer gregarine and water mite parasites. Freshw Biol 60:794-801. https://doi.org/10.1111/fwb.12534

Kaunisto KM, Kaunisto P, Ilvonen JJ, Suhonen J (2017) Parasitism, immune response, and egg production of the spearhead bluet (Coenagrion hastulatum) damselfly. Can J Zool 95:367-372. https://doi.org/10. $1139 /$ cjz-2016-0146

Khan MK (2020) Female prereproductive coloration reduces mating harassment in damselflies. Evolution 74:2293-2303. https://doi.org/10.1111/evo.14048

Lajeunesse MJ, Forbes MR (2003) A comparison of structural size and condition in two female morphs of the damselfly Nehalennia irene (Hagen) (Zygoptera: Coenagrionidae). Odonatologica 32:281-287 
Le Rouzic A, Hansen TF, Gosden TP, Svensson EI (2015) Evolutionary time-series analysis reveals the signature of frequency-dependent selection on a female mating polymorphism. Am Nat 185:E182-E196. https://doi.org/10.1086/680982

Locklin JL (2012) A method for rearing large quantities of the damselfly, Ischnura ramburii (Odonata: coenagrionidae), in the laboratory. Fla Entomol 95:273-277. https://doi.org/10.1653/024.095.0205

Miller MN, Fincke OM (1999) Cues for mate recognition and the effect of prior experience on mate recognition in Enallagma damselflies. J Insect Behav 12:801-814

Nityananda V (2016) Attention-like processes in insects. Proc R Soc b: Biol Sci 283:20161986. https://doi. org/10.1098/rspb.2016.1986

Parr MJ (1999) The terminology of female polymorphs of Ischnura (zygoptera: coenagrionidae). Int J Odonatol 2:95-99. https://doi.org/10.1080/13887890.1999.9748116

Piersanti S, Rebora M, Salerno G et al (2015) A method for rearing a large number of damselflies (Ischnura elegans, coenagrionide) in the laboratory. Int J Odonatol 18:125-136. https://doi.org/10.1080/13887 890.2015.1015179

Piersanti S, Salerno G, Di Pietro V et al (2021) Tests of search image and learning in the wild: Insights from sexual conflict in damselflies. Ecol Evol 11:4399-4412. https://doi.org/10.1002/ece3.7335

Punzalan D, Rodd FH, Hughes AK (2005) Perceptual processes and the maintenance of polymorphism through frequency-dependent predation. Evol Ecol 19:303-320. https://doi.org/10.1007/ s10682-005-2777-z

R Core Team (2016) R: a language and environment for statistical computing. R Foundation for Statistical Computing, Vienna, Austria

Rebora M, Frati F, Piersanti S et al (2018) Field tests of multiple sensory cues in sex recognition and harassment of a colour polymorphic damselfly. Anim Behav 136:127-136. https://doi.org/10. 1016/j.anbehav.2017.12.015

Robertson HM (1985) Female dimorphism and mating behaviour in a damselfly, Ischnura ramburi: females mimicking males. Anim Behav 33:805-809. https://doi.org/10.1016/S0003-3472(85) 80013-0

Rolff J (1999) Parasitism increases offspring size in a damselfly: experimental evidence for parasitemediated maternal effects. Anim Behav 58:1105-1108. https://doi.org/10.1006/anbe.1999.1240

Sánchez-Guillén RA, van Gossum H, Cordero Rivera A (2005) Hybridization and the inheritance of female colour polymorphism in two ischnurid damselflies (Odonata: coenagrioniae). Biol J Linn Soc 85:471-481

Sánchez-Guillén RA, Hammers M, Hansson B et al (2013a) Ontogenetic shifts in male mating preference and morph-specific polyandry in a female colour polymorphic insect. BMC Evol Biol 13:116-116. https://doi.org/10.1186/1471-2148-13-116

Sánchez-Guillén RA, Martínez-Zamilpa SMJ, Jiménez-Cortés JG et al (2013b) Maintenance of polymorphic females: do parasites play a role? Oecologia 171:105-113. https://doi.org/10.1007/ s00442-012-2388-7

Sánchez-Guillén RA, Wellenreuther M, Chávez-Ríos JR et al (2017) Alternative reproductive strategies and the maintenance of female color polymorphism in damselflies. Ecol Evol 7:5592-5602. https://doi.org/10.1002/ece3.3083

Sanmartín-Villar I, Cordero-Rivera A (2016) The inheritance of female colour polymorphism in Ischnura genei (zygoptera: coenagrionidae), with observations on melanism under laboratory conditions. PeerJ 4:e2380. https://doi.org/10.7717/peerj.2380

Schneider CA, Rasband WS, Eliceiri KW (2012) NIH Image to ImageJ: 25 years of image analysis. Nat Methods 9:671-675

Serrano-Meneses MA, Córdoba-Aguilar A, Azpilicueta-Amorín M et al (2008) Sexual selection, sexual size dimorphism and Rensch's rule in Odonata. J Evol Biol 21:1259-1273. https://doi.org/10. 1111/j.1420-9101.2008.01567.x

Sherratt TN, Forbes MR (2001) Sexual differences in coloration of coenagrionid damselflies (odonata): a case of intraspecific aposematism? Anim Behav 62:653-660. https://doi.org/10.1006/anbe.2001. 1789

Sherratt TN, Laird R, a., Hassall C, et al (2010) Empirical evidence of senescence in adult damselflies (odonata: zygoptera). J Anim Ecol 79:1034-1044. https://doi.org/10.1111/j.1365-2656.2010.01719.x

Sirot LK, Brockmann HJ (2001) Costs of sexual interactions to females in rambur's forktail damselfly, Ischnura ramburi (zygoptera: coenagrionidae). Anim Behav 61:415-424. https://doi.org/10.1006/ anbe.2003.2279

Sirot LK, Brockmann HJ, Marinis C, Muschett G (2003) Maintenance of a female-limited polymorphism in Ischnura ramburi (zygoptera: coenagrionidae). Anim Behav 66:763-775. https://doi.org/10. 1006/anbe.2003.2279 
Stearns SC (1992) The evolution of life histories. Oxford University Press, London

Stoks R (2000) Components of lifetime mating success and body size in males of a scrambling damselfly. Anim Behav 59:339-348. https://doi.org/10.1006/anbe.1999.1309

Stoks R (2001) Male-biased sex ratios in mature damselfly populations: real or artefact? Ecol Entomol 26:181-187. https://doi.org/10.1046/j.1365-2311.2001.00301.x

Stoks R, Cordoba-Aguilar A (2012) Evolutionary ecology of odonata: a complex life cycle perspective. Annu Rev Entomol 57:249-265. https://doi.org/10.1146/annurev-ento-120710-100557

Subrero E, Sforzini S, Viarengo A, Cucco M (2019) Exposure to anti-mosquito insecticides utilized in rice fields affects survival of two non-target species, Ischnura elegans and daphnia magna. Paddy Water Environ 17:1-11. https://doi.org/10.1007/s10333-018-0678-3

Svensson EI, Abbott JK (2005) Evolutionary dynamics and population biology of a polymorphic insect. J Evol Biol 18:1503-1514. https://doi.org/10.1111/j.1420-9101.2005.00946.x

Svensson EI, Abbott JK, Hardling R (2005) Female polymorphism, frequency dependence, and rapid evolutionary dynamics in natural populations. Am Nat 165:567-576. https://doi.org/10.1086/429278

Takahashi Y, Kawata M (2013) A comprehensive test for negative frequency-dependent selection. Popul Ecol 55:499-509. https://doi.org/10.1007/s10144-013-0372-7

Takahashi Y, Watanabe M (2009) Diurnal changes and frequency dependence in male mating preference for female morphs in the damselfly Ischnura senegalensis (Rambur) (Odonata: Coenagrionidae). Entomol Sci 12:219-226. https://doi.org/10.1111/j.1479-8298.2009.00326.x

Takahashi Y, Watanabe M (2010a) Mating experience affecting male discrimination between sexes and female morphs in Ischnura senegalensis (Rambur) (zygoptera: coenagrionidae). Odonatologica 39:47-56

Takahashi Y, Watanabe M (2010b) Morph-specific fecundity and egg size in the female-dimorphic damselfy Ischnura senegalensis. Zoolog Sci 27:325-329. https://doi.org/10.2108/zsj.27.325

Therneau TM (2020) A package for survival analysis in S. Version 2.38. CRAN Website https://CRAN.Rproject.org/package $=$ survival

Thompson DJ, Hassall C, Lowe CD, Watts PC (2011) Field estimates of reproductive success in a model insect: behavioural surrogates are poor predictors of fitness. Ecol Lett 14:905-913. https://doi.org/10. 1111/j.1461-0248.2011.01655.x

Torres-Cambas Y, Fonseca-Rodríguez R (2011) Sex ratio, survival, and recapture rate in a Cuban population of the damselfly Hypolestes trinitatis (odonata: megapodagrionidae). Acta Ethologica 14:69-76. https://doi.org/10.1007/s10211-011-0095-8

Van Noordwijk M (1978) A mark-recapture study of coexisting zygopteran populations. Odonatologica 7:353-374

Van Gossum H, Stoks R, Matthysen E et al (1999) Male choice for female colour morphs in Ischnura elegans (Odonata, Coenagrionidae): testing the hypotheses. Anim Behav 57:1229-1232. https://doi.org/ 10.1006/anbe. 1999.1100

Van Gossum H, Stoks R, de Bruyn L (2001) Reversible frequency-dependent switches in male mate choice. Proc R Soc B 268:83-85

Van Gossum H, Stoks R, De Bruyn L (2005) Lifetime fitness components in female colour morphs of a damselfly: density- or frequency-dependent selection? Biol J Linn Soc 86:515-523. https://doi.org/10. 1111/j.1095-8312.2005.00551.x

Van Gossum H, Sherratt TN, Cordero-Rivera A (2008) The evolution of sex-limited colour polymorphism. In: Cordoba-Aguilar A (ed) Dragonflies and damselflies: model organisms for evolutionary research. Oxford University Press, Oxford UK, pp 219-229

Wellenreuther M, Svensson EI, Hansson B (2014) Sexual selection and genetic colour polymorphisms in animals. Mol Ecol. https://doi.org/10.1111/mec.12935

Willink B, Svensson EI (2017) Intra-and intersexual differences in parasite resistance and female fitness tolerance in a polymorphic insect. Proc R Soc Lond B 284:20162407-20162407. https://doi.org/10. 1098/rspb.2016.2407

Winfrey C, Fincke OM (2017) Role of visual and non-visual cues in damselfly mate recognition. Internat J Odonatol 20:43-52. https://doi.org/10.1080/13887890.2017.1297259

Wong-Muñoz J, Córdoba-Aguilar A, Cueva del Castillo R et al (2011) Seasonal changes in body size, sexual size dimorphism and sex ratio in relation to mating system in an adult odonate community. Evol Ecol 25:59-75. https://doi.org/10.1007/s10682-010-9379-0

Zawal A (2006) Phoresy and parasitism: water mite larvae of the genus Arrenurus (acari: hydrachnidia) on odonata from Lake Binowskie (NW Poland). Biol Lett 43:257-276

Publisher's Note Springer Nature remains neutral with regard to jurisdictional claims in published maps and institutional affiliations. 